\title{
HR scenario game: Learning human resource management in a virtual environment
}

\section{Elina Riivari, Tommi Auvinen, Juhani Merilehto}

University of Jyväskylä School of Business and Economics, University of Jyväskylä, Finland.

\begin{abstract}
This paper introduces a computer-based online scenario game that was developed to enhance the learning of human resource management (HRM) in an undergraduate course at a business school in Finland. What makes this game unique is that students played an important and active role in developing the game in collaboration with lecturers. Our findings show that the game enhances learning, interaction, and collaboration among students. We discuss how computer-based games and their development in collaboration with students can be used as a means for learning and improving working-life skills in higher education.
\end{abstract}

Keywords: Computer scenario game; human resource management; game development; collaboration; higher education. 


\section{Introduction}

This paper introduces a computer-based online scenario game that was developed to enhance the learning of human resources management (HRM) in an undergraduate course at a business school in Finland. What makes this game unique is that students played an important and active role in developing the game in collaboration with lecturers. Here, we discuss how computer-based games and their development in collaboration with students can be used as a means for learning in higher education.

The game provides a tool for learning about HRM content, processes, and decision making in HR work. Digitalization, experientialism, collaboration, and combining practical and theoretical knowledge were important ideas during the game's creation and development. Currently, the game is applied in a mass course that involves students from different faculties and disciplines. Engaging students and providing them with participation possibilities as well as written feedback are challenging in courses with dozens or even hundreds of students. However, involving students in game development and facilitation supports their motivation, collaboration skills, and working life capabilities (Cagiltay 2007, Hwang, Hung \& Chen 2014). Moreover, active game development with students supports learning, belonging, and collaboration for students as well as lecturers. These competences and skills are important not only for individual students but also at the institutional level. For example, working in multidisciplinary groups, using innovative digital platforms and tools in teaching, enhancing student involvement as co-actors together with lecturers, developing students' working life capabilities in situations that simulate real-life situations, and continuous development of the game can be seen as important learning objectives, skills, and competences for university graduates. This online game can also be applied in online teaching, which has been important during COVID-19, to provide opportunities to cooperate, interact, and have small group discussions.

This HR scenario game, which aims to engage and group students, simulates practical situations in real working life and prepares students to handle work-related decisions. Playing the game engages students in considering and evaluating the consequences of certain decisions from the managerial, organizational, and employee perspectives. Students play the game and make decisions in small groups, which helps them understand different team roles and objectives.

During the game, the student teams make decisions after taking on the role of a supervisor working in a fast-growing IT company. They are presented with complicated HR situations, such as those related to recruitment and employee wellbeing and development. Instead of dichotomic (right vs. wrong) answer options, the student teams must consider the situations from different perspectives and make decisions together on how to proceed. 


\section{The scenario game as a pedagogical tool}

This HR scenario game was developed for an undergraduate HRM course at a business school in Finland as a tool to enhance students' learning of HRM content and skills. The development and use of the game were based on the constructionist learning approach, which includes collaboration, the active role of learners, and combining theory and practice as its central ideas (Tynjälä \& Gijbels, 2012; Vlachopoulos \& Makri, 2017). Playing the game in collaboration with other students supports interactive learning, especially in virtual environments (García García, Biencinto López, Carpintero Molina, Expósito Casas, \& Ruiz Morales, 2016), and the use of teams makes it possible to discuss and compare different aspects and perspectives, enhances multidiscplinarity if the game is played in multidisciplinary groups, and helps students apply theoretical and conceptual knowledge learned during the course into practice (Wendel, Gutjahr, Göbel, \& Steinmetz, 2013).

This HR scenario game is unique due to its development in active and continuous cooperation with students and lecturers. Students played an important role in creating and developing the content of and facilitating the game. Notably, collaborative learning was not limited to game playing; rather, it also had an important role in the development of the game.

\section{Introducing the HR scenario game}

\subsection{Game description}

The HR scenario game (see Figure 1) was developed for an undergraduate HRM course at a business school. The scenarios consist of eight different HRM content areas (strategic HRM, recruitment practices, recruitment strategy, orientation, leadership, competence development, wellbeing at work, remuneration, and international HRM). The scenarios in the game were created based on an imaginary case company. Players of the game work as supervisors in a five-year-old, fast-growing IT company. At the beginning of the game, the players become familiar with the company's details and current situation. The game was developed to support students' authentic learning experiences of HRM situations by contextualizing the scenarios in the game through the imaginary case company. In addition, having students identify themselves as supervisors gives them an active HR role.

\subsection{Playing and facilitating the game}

Around 400 students at the university and open university attend the course every year. The students at the university represent 6 different faculties, and open university students represent age variation from 18 to 65 years and working experience from trainee to senior HRM professionals with several years of working experience. Thus, versatile backgrounds of the students allow that all of them play the game during the course as members of 
multidisciplinary teams. The game's creators have been teaching the course for several years, and they developed the game to specifically support learning of the course's HR content.

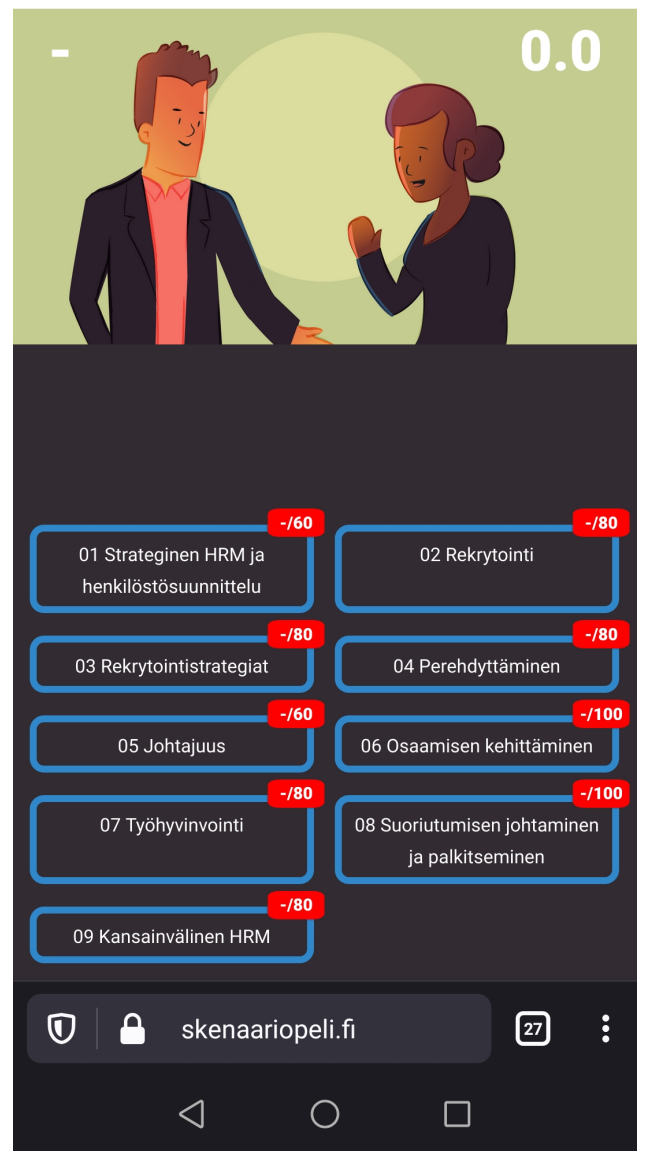

Figure 1. Screenshot of the scenario game Source: www.skenaariopeli.fi (2021).

The game, which is played in small groups (three to four students per team), is a mandatory course assignment for all students. Students attend a demo session, which has game facilitators (master-level students). In autumn 2020, the demo sessions were organized online via Zoom. The students could choose between two demo sessions during which they were randomly divided into small groups of three to four students. Random group division automatically placed students into multidisciplinary groups, which represented different faculties of the multidisciplinary university (e.g., business, education, humanities, IT, science) and backgrounds at the open university (e.g. age, education, working experience).

During the game, the small groups played each scenario at least once. At its best, playing a game can provide emotion-based experiences (Anolli, Mantovani, Confalonieri, Ascolese, \& 
Peveri, 2010), which can enliven other course materials (lectures, literature) and support the achievement of course learning objectives. Before the students started to play, the game facilitators advised the players to have active discussions with their team members while solving the scenarios and taking notes during the game.

After the student teams finished the scenario game, they wrote a reflection report on their learning experiences. In the reflective group report, the students were asked to discuss their experiences and perceptions during the game and to analyze their decisions in the game based on the course materials (literature and lectures). For example, they were advised to reflect on what new information they learned, which scenario they found most interesting, difficult, or confusing and why, and whether they had ever encountered some of the scenarios in their personal lives, including how they reacted.

The game facilitators evaluated the group reports and wrote short feedback comments for each group reflection report. The student teams also self-evaluated their learning, teamwork and its results. The game facilitators were orientated to their role, and they received credits and a certificate as a reward.

\subsection{Collaborative development}

This game is unique for its collaborative development and creation processes. Course lecturers have been responsible for the game development process, but students have also had important and active roles in the game's creation and development. Master-level students have participated in the game's development by ideating new content and acting as game facilitators during the course. This has allowed the graduate students to gain experience in planning, organizing, and digitalized learning through implementing teamwork and facilitating game playing sessions. They also participated in evaluating the game reflections.

\section{Students' experiences with the game}

Next, we present student experiences from the game and discuss how computer-based games and their development in collaboration with students can be used as a means for learning in higher education. Student experiences were collected from reflection reports (altogether 60 reports, with 238 pages of text), and thematic analysis was applied to categorize the students' experiences.

In their reflection reports, the students reported that the game had inspired them to discuss the outcomes together and encouraged some development ideas. The students reported four main themes: increased interaction, support of multidisciplinarity, deepened understanding, and application of the course content (theoretical knowledge learned during the course). Table 1 details these four themes. 
Table 1. Students' experiences with the game.

\begin{tabular}{|c|c|c|}
\hline Theme & Key elements for learning & Illustrative example \\
\hline $\begin{array}{l}\text { Increased } \\
\text { interaction }\end{array}$ & $\begin{array}{l}\text { Deep group discussions } \\
\text { Combining their own experiences } \\
\text { Increased learning and remembering } \\
\text { Collaborative and action-based } \\
\text { opportunities for learning } \\
\text { Online group work and interaction } \\
\text { skills }\end{array}$ & $\begin{array}{l}\text { Cooperating and discussing the questions in the } \\
\text { scenarios with the group helped us succeed in the } \\
\text { game. Playing the game was an informative learning } \\
\text { experience because the game was interesting and } \\
\text { challenged us to think. Playing the game in a group } \\
\text { increased the meaningfulness of gaming. The group } \\
\text { size of four people was perfect because we all had a } \\
\text { chance to offer our opinion and contribute to the } \\
\text { discussion (Group 17). }\end{array}$ \\
\hline $\begin{array}{l}\text { Support of } \\
\text { multidiscplinarity }\end{array}$ & $\begin{array}{l}\text { Multidisciplinary groups as sources of } \\
\text { inspiration } \\
\text { A variety of viewpoints and } \\
\text { perspectives } \\
\text { Sharing their own experiences } \\
\text { Problem-solving and analytical skills }\end{array}$ & $\begin{array}{l}\text { The questions in the game inspired us to consider the } \\
\text { situations from different perspectives. We noticed } \\
\text { that it is not always easy to find an answer to a simple } \\
\text { question. Situations are contextual in nature. The } \\
\text { game showed us that HRM covers a variety of areas, } \\
\text { and handling all these areas requires continuous } \\
\text { development and learning (Group 18). }\end{array}$ \\
\hline $\begin{array}{l}\text { Deepened } \\
\text { understanding }\end{array}$ & $\begin{array}{l}\text { Concrete situations from working life } \\
\text { Understanding the role and tasks of an } \\
\text { HR professional } \\
\text { Highlighting special challenges in } \\
\text { HRM } \\
\text { The possibility of combining previous } \\
\text { experiences from working life with } \\
\text { theoretical knowledge } \\
\text { Increased motivation and } \\
\text { strengthening of previous HRM } \\
\text { knowledge }\end{array}$ & $\begin{array}{l}\text { The game gave us concrete examples of situations } \\
\text { that an HR manager can face and must address at } \\
\text { work. The game provided us with a wider } \\
\text { understanding of an HR manager's role and deepened } \\
\text { our learning (Group } 8 \text { ). } \\
\text { Many members of our group already had experience } \\
\text { with the recruitment process, either as a recruitee or a } \\
\text { recruiter. The real-life experiences enriched our } \\
\text { teamwork and made it easier to understand and } \\
\text { discuss the themes and questions presented in the } \\
\text { scenario game (Group 18). }\end{array}$ \\
\hline $\begin{array}{l}\text { Application of } \\
\text { learned course } \\
\text { content }\end{array}$ & $\begin{array}{l}\text { Increased interest in course content } \\
\text { Discovering an interest in HRM (a } \\
\text { specific area) } \\
\text { Combining theoretical and practical } \\
\text { knowledge } \\
\text { Creating new knowledge by adding to } \\
\text { their previous knowledge base } \\
\text { Action-based learning and real-life } \\
\text { situations from working life }\end{array}$ & $\begin{array}{l}\text { The game supported my learning and added to my } \\
\text { previous knowledge. I read the course book a lot and } \\
\text { learned more. I found certain themes from HRM that } \\
\text { really interest me. The game supported learning } \\
\text { because it made us consider and ponder HRM topics } \\
\text { and themes in a deeper manner. The game covered the } \\
\text { course topics well (Group 3). } \\
\text { The game challenged us to combine and apply } \\
\text { theoretical knowledge into practice. We really needed } \\
\text { to consider which answer would be correct based on } \\
\text { the theory (Group 7). }\end{array}$ \\
\hline
\end{tabular}




\section{Concluding remarks}

This study described how a computer-based online scenario game can be applied in an undergraduate HRM course and how its development and application can enhance students' learning, collaboration, and interaction. As we have illustrated, the students appreciated the interactive and collaborative aspects of the learning experience through the game. Especially working, sharing experiences and discussing in small groups were important for increased interaction and collaborative learning. Various backgrounds of students allowed students to discuss different aspects and perspectives during the game play. Thus, multidisciplinarity offered them not only increased interdisciplinary knowledge but sources of inspiration and improved analytical and problem-solving skills.

The positive experiences with developing and using the game in teaching have encouraged lecturers to the use of games in teaching at the higher education level as a means of enhancing students' learning, increasing their interest in the course content, and adding to their workinglife skills as business graduates and future experts in the field. The game is unique for its collaborative development and creation processes where students have had an important role as active game developers and facilitators. These positive experiences can encourage also other higher education professionals to applying games in their teaching, and engaging and offering participation possibilities to students during courses.

\section{References}

Anolli, L., Mantovani, F., Confalonieri, L., Ascolese, A., \& Peveri, L. (2010). Emotions in serious games: From experience to assessment. International Journal of Emerging Technologies in Learning (iJET), 5, 7-16.

Cagiltay, N. E. (2007). Teaching software engineering by means of computer-game development: Challenges and opportunities. British Journal of Educational Technology, $38(3), 405-415$.

García García, M., Biencinto López, C., Carpintero Molina, E., Expósito Casas, E., \& Ruiz Morales, Y. A. (2016). Development and evaluation of the team work skill in university contexts. Are virtual environments effective? International Journal of Educational Technology in Higher Education, 13(5), 1-11. https://doi.org/10.1186/s41239-016-00141

Hwang, G. J., Hung, C. M., \& Chen, N. S. (2014). Improving learning achievements, motivations and problem-solving skills through a peer assessment-based game development approach. Educational Technology Research and Development, 62(2), 129145.

Tynjälä, P., \& Gijbels D. (2012). Changing world: Changing pedagogy. In P. Tynjälä, M. L. Stenström, \& M. Saarnivaara (Eds.), Transitions and transformations in learning and education (205-222). Netherlands: Springer. 
Vlachopoulos, D., \& Makri, A. (2017). The effect of games and simulations on higher education: A systematic literature review. International Journal of Educational Technology in Higher Education, 14(22), 1-33. https://doi.org/10.1186/s41239-0170062-1

Wendel, V., Gutjahr, M., Göbel, S., \& Steinmetz, R. (2013). Designing collaborative multiplayer serious games. Education and Information Technologies, 18(2), 287-308. https://doi.org/10.1007/s10639-012-9244-6 